\title{
身体発育と初潮年齢との関係について
}

\section{The relationship between physical development and menarcheal age.}

\author{
京都府立医科大学衞生学教室（主任 額田粲教授） \\ 石 原 栄 美子 \\ Emiko Ishihara
}

Department of Hygiene, Kyoto Prefectural School of Medicine

(Director: Prof. A. Nukada)

\section{まえがき}

前報に扮いて著者は兵庫県下の新制中学三年女生徒553 22名について初潮年令の地域差を調査し，とれが主とし て地域による産業構造の差にもとずくことを報告した。

同一の資料を用い身体発育と初潮年令との関係につい て調查したので報告する。

\section{調查方法}

前報の調査対象5322例中必要事項の記入のないもの， 記入事項の不確実なもの愉外し, 記入事項の完全なカ ード4778枚について集計を行つた。身長，体重，胸囲决 昭和33年 4 月に打ける身体検査の結果を用いこれより比 体重, 比胸囲, を算出した。

\section{調 査結 果}

\section{1，初潮年棓と身体発育との関係}

表 1 は初潮年命と身体発育との関係である。13才未満
ですでに来潮をみた場合には身長が最も高く，14才 6 カ 月以後の者ては一番低い。

要するに早く初潮のあった者程身長は高い。各年令の 間の身長の差学検定してみると,13才迄淿初潮のあった 者は 14 才以後の来潮者に比し $1 \%$ 以下の危険率で有意の 差を示している。

胸囲についても又身長と略同様の結果を示し初潮の早. くあった者程胸囲は大きい。又13才迄に初潮のあった者 では胸囲が最も大きく，他の年令階級との間にはいずれ も危険率 $1 \%$ 以下で有意の差が認められた。

全く同様の関係注体重についても認められ，夫火の初 潮時期による階層の間には $1 \%$ \%下の危険率で有意の差 のある事がわかった。

比胸囲，比体重についても関係は全く同様であるが， 比胸囲の場合には13〜14才，14〜14才 6 カ月の間に忟有・ 意の差は認められなかった。

比体重については各くの初潮年令階層の間に $1 \%$ 以下 の危険率で有意の差が認められた。

表 1 初潮年筁と身体発育との関係

\begin{tabular}{|c|c|c|c|c|c|c|c|c|c|c|c|}
\hline 身体登 & \multirow{2}{*}{ 例数 } & \multicolumn{2}{|l|}{ 身 } & \multicolumn{2}{|l|}{ 胸 } & \multicolumn{2}{|c|}{ 体重 } & \multicolumn{2}{|c|}{ 比胸 囲 } & \multicolumn{2}{|c|}{ 比体重 } \\
\hline${ }^{1}$ 年齢 & & 平圴値 & 標偏 & 平圴値 & 標偏 & 平圴値 & 標偏 & 平圴值 & 標偏 & 平圴値 & 標偏 \\
\hline 13 歳末満 & $631^{\text {名 }}$ & $\begin{array}{r}\mathrm{cm} \\
152.0\end{array}$ & 5.15 & 77.7 & 4.52 & $47.4^{\mathrm{kg}}$ & 5.63 & 51.0 & 2.98 & 30.8 & 2.87 \\
\hline 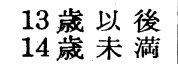 & 1,759 & 151.4 & 5.14 & 76.5 & 4.62 & 45.7 & 5.43 & 50.4 & 3.11 & 30.0 & 2.81 \\
\hline $\begin{array}{l}14 \text { 歳以後 } \\
14 \text { 歳末満 }\end{array}$ & 972 & 150.3 & 5.38 & 75.8 & 4.50 & 44.2 & 5.51 & 50.4 & 2.98 & 29.4 & 2.64 \\
\hline 14.5嵅以後 & 1,416 & 148.8 & 5.67 & 74.2 & 5.48 & 42.3 & 5.47 & 49.7 & 3.14 & 28.4 & 2.75 \\
\hline 計 & 4,778 & 150.5 & 5.50 & 75.8 & 4.80 & 44.6 & 5.76 & 50.3 & 3.10 & 29.5 & 2.88 \\
\hline
\end{tabular}


表 214.5 歲後で調查時現在初潮のあつた者と初潮のない者との比較

\begin{tabular}{|c|c|c|c|c|c|c|c|c|c|c|c|}
\hline 身体 & \multirow{2}{*}{ 例数 } & 身 & 長 & 胸 & 囲 & 体 & 重 & \multicolumn{2}{|c|}{ 比胸团 } & \multicolumn{2}{|c|}{ 比体重 } \\
\hline の有無 & & 平均值 & 標偏 & 平均値 & 標偏 & 平圴値 & 標偏 & 平圴値 & 標偏 & 平圴値 & 標偏 \\
\hline 有 経 者 & 1,037 & $\begin{array}{r}\mathrm{cm} \\
149.5\end{array}$ & 5.25 & $75.5^{\mathrm{cm}}$ & 4.39 & $43.2^{\mathrm{kg}}$ & 5.21 & 50.3 & 2.84 & 29.3 & 2.51 \\
\hline 末 潮 者 & 379 & 146.8 & 6.38 & 72.5 & 4.71 & 39.6 & 5.21 & 49.5 & 3.17 & 27.6 & 2.63 \\
\hline
\end{tabular}

表 2 は14才 6 力月以前に初潮をみなかった者を調査時 現在いまだ初潮のなかつた者 379 名と調査時現在初潮を 見た者1,037 名とに分けたものである。

両者の身長の平均学求めて見るとその差は $3 \mathrm{~cm}$ に及 んでいることがわかった。

Fluhmann" も同年令の間では 既に初潮のあった者は その年令の間の平均身長よりも高い事を述べている。

胸囲についても調查時においてまだ初潮のない者では 明らかて来潮者にくらべ胸囲がせまく両者の差は $3 \mathrm{~cm}$

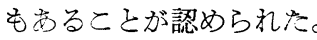

体重についても同様いまだ初潮のないものでは来潮者 より約 $3.5 \mathrm{~kg}$ も少い。

比胸囲，比体重う亦上記の結果より見て未初潮者は劣 つている事がわかった。

松林2) 核初潮の発来は身長が $148 \mathrm{~cm}$ に達した時に沶 こると述べているが, 本調査においても14才 6 力月以後 の来潮者の身長は平均 $149.5 \mathrm{~cm}$, 調查時現在来潮のな いむのでは平均 $146.8 \mathrm{~cm}$ であるから平均值としては松 林 ${ }^{2)}$ の所説にほほ济近い值を示している。松林 ${ }^{21}$ の研究は その後多くの研究者に引用されているが，いずれの研究 者も初潮時の身長の 分布のみを取りあげ，乙の平均が $148 \mathrm{~cm}$ 程度であるととを認めている。との様な議論の 進內方からすれば, 身長のみならず, 胸囲, 体重につい ても全く同様の結論が得られ, 胸囲, 体重が一定値に達 すれば初潮がおこると云うことになると思われる。

何故なら胸囲, 体重は身長上の間に一次式の関係が見
出されるからである。少なくとも，環境条件が一定とみ なされる一地域の女学生, 或はある特定校についての研 究ならばそのような帰結は計算にまつまでもなく成立す るものと思われる。

松林はその論文中に女学校入学前に初潮を見た者と, 卒業後初潮を見たついて女学校在受中の身長, 体重, 比 体重の経過を示している。これを第 2 表こ対照してみる と, いずれも初潮時に抬いて仿体重は $42 \mathrm{~kg}$ 強, 比体重 は29弱であり，このような推論には間違のないことがわ かる。

要するに初潮が身長, 体重, 胸囲等体格の要素のいず れに最も関係が深いかをしらべるためには，同一環境条 件に沶かれている女子の体格を分析すると云う以上のよ らな方法では解決されない。

との点を解明するためには異った環境下に怙かれてい る者について体格と初潮との関係を調査しなければなら ない。

\section{2. 地域差と身体発育との関係}

表 3 は地域別の身体発育状態を示す表である。前報に 述べた様に瀬戸内海地方では初潮年令が最も早く, 日本 海地方では最も遅い。身長については初潮の早い瀬戸内 海地方が最も高く, 初潮の括てい日本海地方が最も低 w。

両者の身長の間には $1 \%$ 以下の危険率で有意の差が認 められた。

胸囲について地域差を見るこ日本海地方では胸囲が最

表 3 地域差と身体発筒との関係

\begin{tabular}{|c|c|c|c|c|c|c|c|c|c|c|c|}
\hline 身 & \multirow{2}{*}{ 例数 } & \multicolumn{2}{|l|}{ 身 } & \multicolumn{2}{|c|}{ 胸 团 } & \multicolumn{2}{|l|}{ 体 } & \multicolumn{2}{|c|}{ 比胸囲 } & \multicolumn{2}{|c|}{ 比体重 } \\
\hline & & 平圴値 & 標偏 & 平圴值 & 標偏 & 平均值 & 標偏 & 平均値 & 標偏 & 平均値 & 標偏 \\
\hline 日 本 海 & \begin{tabular}{r|} 
名 \\
1,252
\end{tabular} & $\begin{array}{r}\mathrm{cm} \\
150.1\end{array}$ & 5.56 & $76.4^{\mathrm{cm}}$ & 4.68 & $44.6^{\mathrm{kg}}$ & 6.06 & 50.6 & 2.95 & 29.6 & 2.98 \\
\hline 間 & 945 & 150.6 & 5.59 & 76.2 & 4.76 & 44.9 & 5.85 & 50.5 & 3.04 & 29.6 & 2.97 \\
\hline 瀬戸内海 & 1,560 & 150.7 & 5.40 & 75.2 & 4.96 & 44.5 & 5.64 & 49.8 & 3.20 & 29.4 & 2.83 \\
\hline 島 嗗 & 1,021 & 150.5 & 5.31 & 75.7 & 4.72 & 44.4 & 5.50 & 50.4 & 2.99 & 29.5 & 2.76 \\
\hline 計 & 4,778 & 150.5 & 5.50 & 75.8 & 4.80 & 44.6 & 5.76 & 50.3 & 3.10 & 29.5 & 2.88 \\
\hline
\end{tabular}


も大きく, 瀬戸内海地方が最も小さく初潮年令の遅速と は逆の傾向がみられた。

この場合瀬戸内海掞よび日本海, 瀬戸内海扣よび山間 との間には夫々 $1 \%$ 以下の危険率で有意の差が認められ た。

体重についても初潮の早い瀬戸内海地方, 島渙, より む山間, 日本海方面在住者方やや大きい傾向が認められ る。この場合体重が最も大きい山間地方乞, 体重が最も 小さい島渙ては夫々 $1 \%$ 以下で有意の差が認められた。

比胸囲, 比体重についても瀬戸内海地方では其地の地 方より小さい傾向が認为られる。

殊に比胸囲については地域差は有意の差と認められ, 初潮年命の早い瀬戸内海地方が最も小さく, 来潮の遅い 日本海地方に打いて最も大きい。乙の両地方と地の三地 区との差はいずれも1\%以下の危険率で有意の差と認め られる。

要するに初潮年令の早い地域程身長は高いが胸团, 体 重, 比胸囲, 比体重については必らずしも地域の平均初 潮年命上の相関が認められない。全般的记注初潮年令の 早い者程身長のみならず, 胸囲, 体重の発育む良好であ るが, 地域別の平均胸囲, 体重と地域別の平均初潮年令 とはさしろ逆の相関が認わられたわけである。

八木 ${ }^{31}$ (1930) 沙地区扮よび地勢と成表との関係につ いて日本各地の統計を括めているが，本調査こ同じく兵 庫県の男女学童についての統計では, 都会掞よび山間, 農業地区等に扮ける身長, 体重, 胸囲についての発育は この時代に括いてもすでに身長䄈都会の密集地, 即ち太 平洋岸に捛いて高く, 山間僻地に向って低下寸る傾向が あり特に女子技いて著しいととを認的ている。しかし 体重は身長の低い山間僻地仗括いても都市と大差がな く, 胸囲についてはむしろ山間僻地の方が大きいと報告 している。

又渡辺4（1956）快会津地方の小, 中学生の発育につ

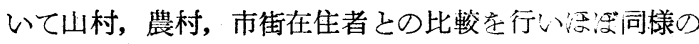
結果を述べ，体重虫環境条件に対して牥京鸟鋭敏では なく, 又胸囲の発育には身長と注異った要因汇関係があ る様に思われると報告している。

渡辺"（1956），城山5)（1943）等沈のような発育の 地域差性生後 $5 \sim 6$ カ月頃よりすでに始まると述べてい る。

\section{3. 初湖年齡を一定にした坦合の地域差と身体発育と の関係}

表 4 は初潮年令が同一の場合について発育の地域差が 認められるか否かを検定した結果である。この場合身
表 4 地域と身体発育関係の梌定

\begin{tabular}{|c|c|c|c|c|c|c|}
\hline 身体発育 & 例数 & 身長 & 胸囲 & 体重 & 比胸囲 & 比体重 \\
\hline 13 歳末 満 & $\begin{array}{r}\text { 名 } \\
631\end{array}$ & $\begin{array}{r}\mathrm{cm} \\
14.10\end{array}$ & $\begin{array}{r}\mathrm{cm} \\
42.82\end{array}$ & \begin{tabular}{r|}
$\mathrm{kg}$ \\
19.10
\end{tabular} & 22.12 & 11.52 \\
\hline $\begin{array}{l}13 \text { 歳以後 } \\
14 \text { 歳満 }\end{array}$ & 1,759 & 18.08 & 53.57 & 16.81 & 44.95 & 11.40 \\
\hline $\begin{array}{l}14 \text { 歳以後 } \\
14.5 \text { 葴末満 }\end{array}$ & 972 & 6.60 & 47.65 & 12.97 & 55.63 & 6.87 \\
\hline 14.5 歳以後 & 1,417 & 23.03 & 21.20 & 18.20 & 19.64 & 9.62 \\
\hline \multicolumn{2}{|c|}{$\begin{array}{c}\text { 分割表に扣りる } \\
\text { 階 級 数 }\end{array}$} & \begin{tabular}{|l|}
$4 \times 4$ \\
又は \\
$4 \times 5$
\end{tabular} & \begin{tabular}{|l|}
$4 \times 6$ \\
又は \\
$4 \times 5$
\end{tabular} & $\mid \begin{array}{l}4 \times 6 \\
\text { 又は } \\
4 \times 4\end{array}$ & $4 \times 4$ & \\
\hline
\end{tabular}

（太数字は $\chi^{2}$ 恰定の結果有意の差のあるもの定示す）

長, 胸囲, 体重, 比胸囲, 比体重注それぞれ表の最下欄 に示す分割表としては 4 地域について $4 \times \mathrm{n}$ 表として 検查を行ったものである。

身長に扮いては初潮年令が同じ場合に地域的な差泣殆 えどみられず，た初潮か最も抢そい14才 6 力月以後の 階層沈执いての交地域差は $5 \%$ 以下で有意の差として認 められる。

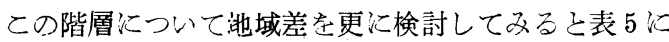
示すょうに日本海方面では身長の高い者が少なく，低い 者が多い事締因しているととがわかった。要すると初 潮を見ない場合汇の及地域差が認められたわけである。

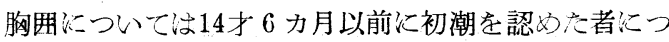
いてはいずれの階層についても $1 \%$ \%下の危険率で地域 差が有意の差として認められる。その内容を検討して見 ると瀬戸内海地方では胸囲の小さい者が多く, 日本海方 面怙よび山間地方では胸囲の大きい者が多い傾向が認め られる。表 5 は各の一例として初潮年令13〜14才刀場合 である。このような結果を生じを理由は胸囲第 2 次性 徵の発現と深い関係があるためと思われる. 即方第 2 次 性徴の発現は初潮の発現より早く抢こるため地域的な環 境条件の差が著しく現れているすのと考えられる。

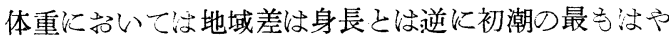
く見られた群, 即ち13才未満に初潮を見た者にの久有意 の差がみられる。この場合 $x^{2} の$ 值を検討してるると表 5 に示すよ3に日本海側には体重の重い者が多く, 反対に 島舆では体重の軽い者が多いという傾向が $5 \%$ 以下の危 険率で有意の差として認められた。

体重は胸囲程著明な地域差の認められないの络，体重 快身長と密接な関係があるためと思われる。一般化量育 は長育より晾くれて発現すると云われている心゙, 本調査 に执いても初潮後一定の年月を経過した者についての及 
表 5 初潮年齢一定の場合の地域差と身体発育との関係

身長 初潮年秢 14.5 歳以後

\begin{tabular}{|c|c|c|c|c|c|c|c|c|c|c|c|}
\hline \multirow[b]{2}{*}{ 地 域 別 } & \multicolumn{2}{|c|}{$140 \mathrm{~cm}$ 以下 } & \multicolumn{2}{|c|}{$140 \sim 145$} & \multicolumn{2}{|c|}{$143 \sim 150$} & \multicolumn{2}{|c|}{$150 \sim 155$} & \multicolumn{2}{|c|}{ 155以上 } & \multirow{2}{*}{ 計 } \\
\hline & 例数 & 期待値 & 例数 & 期待值 & 例数 & 期待値 & 例数 & 期待値 & 例数 & 期待値 & \\
\hline 日 本 海 & 37 人 & 23.3 & 75人 & 76.1 & 146 人 & 137.2 & 142 人 & 138.2 & 28人 & 50.2 & 428 人 \\
\hline 山 間 & 16 & 19.0 & 56 & 55.0 & 94 & 99.7 & 99 & 99.7 & 44 & 36.2 & 309 \\
\hline 瀬戸内海 & 22 & 23.5 & 66 & 68.2 & 121 & 122.8 & 125 & 123.6 & 49 & 44.9 & 383 \\
\hline 島嬹 & 12 & 18.2 & 55 & 52.7 & 93 & 94.9 & 91 & 95.5 & 45 & 34.7 & 296 \\
\hline 計 & \multicolumn{2}{|c|}{87} & \multicolumn{2}{|c|}{252} & \multicolumn{2}{|c|}{454} & \multicolumn{2}{|c|}{457} & \multicolumn{2}{|c|}{166} & 1,416 \\
\hline
\end{tabular}

$$
\chi^{2}=23.03 \quad \mathrm{P}<0.05
$$

胸囲初潮年柃 13 歳 14 歳

\begin{tabular}{|c|c|c|c|c|c|c|c|c|c|c|c|}
\hline \multirow{2}{*}{ 地域別 } & \multicolumn{2}{|c|}{$71 \mathrm{~cm}$ 以下 } & \multicolumn{2}{|c|}{$71 \sim 75$} & \multicolumn{2}{|c|}{$75 \sim 79$} & \multicolumn{2}{|c|}{$79 \sim 83$} & \multicolumn{2}{|c|}{ 83以上 } & \multirow{2}{*}{ 計 } \\
\hline & 例数 & 期待値 & 例数 “ & 期待値 & 例数 & 期待値 & 例数 & 期待值 & 例数 & 期待值 & \\
\hline 日 本 海 & 27人 & 47.9 & 92 人 & 108.1 & 125 人 & 120.3 & 119 人 & 93.0 & 40 人 & 33.7 & 403人 \\
\hline 山 間 & 24 & 39.1 & 82 & 88.3 & 103 & 98.2 & 88 & 75.9 & 32 & 27.5 & 329 \\
\hline 瀬戸内海 & 96 & 72.2 & 178 & 163.2 & 181 & 181.5 & 117 & 140.4 & 36 & 50.8 & 608 \\
\hline 島 嶼 & 62 & 49.8 & 120 & 112.4 & 116 & 125.1 & 82 & 96.7 & 39 & 35.0 & 419 \\
\hline 計 & \multicolumn{2}{|c|}{209} & \multicolumn{2}{|c|}{472} & \multicolumn{2}{|c|}{525} & \multicolumn{2}{|c|}{406} & \multicolumn{2}{|c|}{147} & 1,759 \\
\hline
\end{tabular}

体重 初潮年龄 13 歳末満

\begin{tabular}{|c|c|c|c|c|c|c|c|c|c|}
\hline \multirow{2}{*}{ 地域別 } & \multicolumn{2}{|c|}{$40 \mathrm{~kg}$ 以下 } & \multicolumn{2}{|c|}{$40 \sim 45$} & \multicolumn{2}{|c|}{$45 \sim 50$} & \multicolumn{2}{|c|}{ 50以上 } & \multirow{2}{*}{ 計 } \\
\hline & 例 数 & 期待値 & 例 数 & 期待値 & 例 数 & 期待値 & 例 数 & 期待值 & \\
\hline 日 本 海 & 7 人 & 10.2 & $31^{\text {人 }}$ & 42.8 & ${ }_{43}$ 人 & 44.0 & $62^{\text {人 }}$ & 46.0 & $143^{2}$ 人 \\
\hline 山 間 & 5 & 8.1 & 38 & 33.8 & 35 & 34.7 & 35 & 36.4 & 113 \\
\hline 瀬戸内海 & 22 & 18.7 & 77 & 78.5 & 83 & 80.5 & 80 & 84.3 & 262 \\
\hline 島䑂 & 11 & 8.1 & 43 & 33.8 & 33 & 34.7 & 26 & 36.4 & 113 \\
\hline 計 & \multicolumn{2}{|c|}{45} & \multicolumn{2}{|c|}{189} & \multicolumn{2}{|c|}{194} & \multicolumn{2}{|c|}{203} & 631 \\
\hline
\end{tabular}

比胸囲初潮年粭 13 歳 14 歳

\begin{tabular}{|c|c|c|c|c|c|c|c|c|c|}
\hline \multirow{2}{*}{ 地 域 別 } & \multicolumn{2}{|c|}{$48 \mathrm{~kg}$ 以下 } & \multicolumn{2}{|c|}{$48 \sim 51$} & \multicolumn{2}{|c|}{$51 \sim 54$} & \multicolumn{2}{|c|}{ 54以上 } & \multirow{2}{*}{ 計 } \\
\hline & 例 数 & 期待値 & 例 数 & 期待值 & 数 & 期待値 & 例 数 & 期待値 & \\
\hline 日 本 海 & $50^{\text {人 }}$ & 71.6 & $114^{\text {人 }}$ & 133.6 & $166^{\text {人 }}$ & 136.5 & $73^{人}$ & 61.4 & 403 人 \\
\hline 山間 & 49 & 58.4 & 100 & 109.0 & 129 & 111.4 & 51 & 50.2 & 329 \\
\hline 瀬戸内海 & 135 & 107.6 & 218 & 201.5 & 184 & 206.1 & 71 & 92.6 & 608 \\
\hline 島 嬹 & 78 & 74.4 & 151 & 138.9 & 117 & 142.0 & 73 & 63.8 & 419 \\
\hline 計 & & & & & & & & & 1,759 \\
\hline
\end{tabular}


に地域差が認められることもこれに帰因していると思わ れる。

比胸囲についても地域差が 有意の差として認められ る。しかしこの場合は初潮年令の遅い場合にも, 早い場 合にも瀬戸内海方面では比胸囲が小さい者が多く，日本 海方面および山間部では比胸囲が大きい者が多い。表 5 はその一例としての初潮年令13〜14才の場合である。 比体重の場合には初潮年令の如何にかかわらず有意の 地域差は認められない。

以上の結果から初潮は主として長育に左右されると云 ろ今日迄の文献は再確認された。

長育は一般に環境条件により著しい影響を受けるが， これが一定値に達すると初潮が見られる。この場合体 重, 即ち量育は長育よりやや括くれるが，身長との相関 がつよいため，初潮年令が同程度の場合には地域による 生活環境の差の影響, 即与地域差はかくされてしまう。 しかし初潮を見てから後或る程度経過すると量育につい ても生活環境の影響を受けるようである。

胸囲は初潮を見る以前よりすで増加し始め又環境の 影響も長育と幅育とに対しては全く異った意味を持って いるものと思われる。

\section{結 び}

初潮年令と身体発育との関係について兵庫県下公立中
学三年生女子 4778 名を調查し，次の結果を得た。

1）一般汇初潮年令の早いもの程身長, 体重, 胸囲之: も火大きいが, 初潮年令, 地域差等を考慮に入れると, 各々の意味づけは異って来る。

2）発育には地域的環境条件による影響分つよいが, ある程度以上に発育すると初潮が発現する。この場合初” 潮の発現に最も強い影響を与えるものは身長である。

3）体重は身長より打くれて発達し，地域環境条件に よる影響柱初潮発現後にも及ぶ。

稿を終るに臨み御指導，御校閲を賜つた額田教授に心 加ら感啸致しますと共に芦屋保健所山下辰夫先生の御援 助にあつく柇申上げます。

（本論交の 要旨は第 16 回日本公衆衛生学会に 和いて発: 表した）

\section{文 献}

1) C. F. Fluhmann : Davis and Carter. Gynecol and Obst. 1-2 (1959).

2）松林銷三 : 民族衛生，2（1932）.

3）八木高次 : 横手社会衛生㬝書, 21 (1936).

4）渡辺克：民族衛生，25-1（1959）。

5）城山英太郎：体質医学研究報告，4（1953）.

（受付：1960 年 7 月 4 日） 